Marina Jajić Novogradec Cross-lexical Interactions in Relation to Metalinguistic...

УДК 81.23 DOI 10.30982/2077-5911-2019-41-3-147-155

\title{
CROSS-LEXICAL INTERACTIONS (CLI) IN RELATION TO METALINGUISTIC AWARENESS AND MULTILINGUAL PROFICIENCY IN RUSSIAN AS L3
}

\author{
Marina Jajić Novogradec \\ Teaching Assistant at the Department of Russian Language \\ Faculty of Humanities and Social Sciences of the University of Zagreb \\ Ivana Lučića 3, Zagreb \\ mjnovo@ffzg.hr
}

The aim of the study was to investigate the role of metalinguistic awareness and multilingual proficiency in English and Russian lexical interactions by Croatian students acquiring English as L2 and Russian as L3. A synonym provision task was used as the main instrument to measure the instances of CLI in the written Russian language production. Language proficiency was measured by students' self-assessment in all the three languages and their grade in language courses at the university. The results showed that, apart from students' high level of proficiency in Croatian and English and their metalinguistic awareness, there are other factors, like exposure to languages, psychotypology and recency, that should be taken into consideration while dealing with cross-linguistic studies in multilingual language acquisition.

Keywords: cross-lexical interactions, metalinguistic awareness, multilingual proficiency, English as L2, Russian as L3

\section{Introduction}

The term crosslinguistic influence is often referred to as the influence of one language (usually the first language of an individual) on another (an individual's second or foreign language). Jarvis \& Pavlenko [2008:3-4] point out that some scholars have suggested that crosslinguistic influence, earlier defined as a theory-neutral term by Kellerman and Sharwood Smith in the mid 1980s, may be an inappropriate term to refer to the phenomenon, given that the influence of one language on another in an individual's mind may be more an outcome of an integrated multicompetence than of the existence of two (or more) completely separate language competences in the mind.

Nowadays, it is very common to talk about crosslinguistic interaction, a new concept proposed by Herdina \& Jessner [2002]. The authors describe crosslinguistic interaction (CLIN) not only as a transfer, interference, code-switching or borrowing phenomenon, which results from the interaction of two or more language systems, but it is also intended to cover another set of phenomena as non-predictable dynamic effects which determine the development of the systems themselves and are particularly observable in multilingualism [Herdina \& Jessner 2002: 29].

Our study aims at analysing the most explored area of CLIN and that is the area of lexis. According to De Angelis [2007] non-native linguistic influence is particularly visible in the area of lexis, where traces of non-target information are mostly overt and therefore easily recognizable. Multilingual learners' lexical production is affected by numerous factors. Hall \& Ecke [2003:73] divide factors conditioning cross-lexical influence into those with regard to learners (psychotypology and metalinguistic awareness, motivation, attitude, age, learning style and strategy use, degree of anxiety), learning (language proficiency, L2 status, recency of exposure and use, exposure to languages and use of languages), language (typological distance, historical distance, degree of contact (borrowing), type of writing systems), event (language mode, task, style, language control) and word (degree of formal similarity with competitors, content vs. function word status, frequency). 
The two factors we have given most attention to in the study are metalinguistic awareness and language proficiency, which we analyse in the context of cross-lexical interactions in multilingual students' mental lexicon.

\section{Previous studies of cross-lexical interactions}

Studies of cross-lexical interactions have been increasing recently, as the lexis is considered the key language subsystem that should be acquired by students. In other words, the lexis serves as the basis for building up the other language subsystems, such as morphology and syntax. Therefore, multilingual lexical acquisition seems to be crucial, but still underexplored phenomenon in recent psycholinguistic studies. For the purpose of our study we will review several studies dealing with cross-linguistic influence in lexical production.

Gabryś-Barker [2006] studied cross-lingustic influence in L3 German by students whose L1 was Portuguese, L2 English and L3 German. One group of students was to translate a text from L1 into L3, while the other group from L2 into L3. The results showed that students used more a word-for-word translation from L1 into L3, and as explained by the author, the performance focused on either automatic solutions to individual words offered or a very limited search on individual lexical items, focusing on their semantic equivalence [Gabryś-Barker 2006:162]. In the text translation from L2 into L3 students did not rely on individual items of the words, but they tried to process the text. More influence could be seen from students' L1 than L2.

Another study worth mentioning is that of Ó Laoire \& Singleton [2009] who examined the learning of French as an L3 by Anglophone students of French, whose L 2 was Irish and by balanced bilinguals of Irish and English. The synonym/antonym provision task was used, and the results showed more lexical influence from students L1 English on the word production in L3 French. According to the authors this might be explained by the lexical closeness of English and French, therefore psychotypological factor has played a crucial role in this case.

On the other hand, Lindquist's study [2009] investigated the influence of learners' L1s (Swedish, Spanish, English) and L2s (English, Swedish, German, Finnish, Irish) on L3 French in the oral production. Firstly, a group of 30 Swedish learners was analysed according to their previous exposure to French. The analysis showed that the crosslinguistic lexemes were highly produced by the least advanced learners, whereas more background languages were intertwined. In the second part of the study six case studies of learners with different L1s and L2s were examined. Swedish as L1 or L2, and English as L1 were mostly used by learners as instrumental languages in eliciting metalinguistic functions and in restructuring the utterance, which can be explained by the common access to the languages and learner's knowledge about interlocutor's linguistic competence [Lindquist 2009:293-294].

Letica Krevelj [2014] examined the effect of prior languages, L1 Croatian/Italian and L2 Italian/Croatian on the use of lexis in L3 English, using synonym provision task. The author concentrated on the role of pychotypology and L2 status, which were not completely confirmed. Nevertheless, the study came out with the results that we should distinguish the role of psychotypology at the language system level and psychotypology at the level of individual lexical item.

The studies reveal different roles of all the languages included in one's mind and confirm the significance of many individual factors. Sometimes one factor being examined can be dependent of another factor in the analysis, and there is always a constant interaction between them. That is why studies of cross-linguistic interactions demand a careful methodology to be used along with different languages acquired by learners. In foreign language production, whether written or spoken, languages will show different roles, particularly affected by learner-based and learning-based factors. 
Marina Jajić Novogradec Cross-lexical Interactions in Relation to Metalinguistic...

\section{Metalinguistic awareness as a learner-based factor and language proficiency as a learning-based factor}

Studies that take into consideration metalinguistic awareness and its possible effect on multiple language acquisition have been increasing [Lasagabaster 1998a; Lasagabaster1998b; Gibson \& Hufeisen 2003; Jessner 2003; Jessner 2006], and it is always the positive role of metalinguistic awareness that has been confirmed. The metalinguistically aware multilingual learner explores and analyzes points of commonality between her or his language systems to obtain the target language item [Jessner 2006].

Nowadays, the concept of metalinguistic awareness is very essential in foreign language education, both for teachers and students. Although metalinguistic awareness is considered a learner-based factor, as it depends more on learners' inner processes in their mental lexicon, it can be partly regarded as a learning-based factor, especially in formal environments.

García [2008] puts an emphasis on Wright's [2002] two distinctions of the roles of language awareness. The first role encompasses the development of the teachers' sensitivity to language, and according to the second role, language awareness serves as a method, a task or activity type students work with authentic language data [García 2008: 386]. Based on Wright's view, metalinguistic awareness includes not only the individual's analyses of the languages in the mind, but the whole learning process, too.

Since individual plurilingualism has become more and more popular in the European formal context, which means that many learners have the opportunity to learn two or more foreign languages in their compulsory education, the importance of multilingual awareness among teachers and learners can lead to learners' higher proficiency in foreign language learning. The relationship between metalinguistic awareness and language proficiency in multilingual language acquisition has been discussed by Tkachenko [2011], whose study revealed that presentation of a word in one language automatically activated words from all the other languages in parallel, but the strength of links which were activated was different and it depended on the proficiency of the languages known by the students.

Language proficiency is also often investigated and discussed in combination with other individual factors, such as length of exposure to languages [Tremblay2006], recency [Angelovska \& Hahn 2012; Jajić Novogradec 2017], order of languages being learned [Jessner2008a], psychotypology [Letica Krevelj 2014], school grade [Navés et al. 2005]. It is important to point out Jessner's [2008b] view that in the dynamic model of multilingualism [Herdina \& Jesssner 2002] mulitlingual proficiency is defined as the dynamic interaction among the various psycholinguistic systems $\left(\mathrm{LS}_{1}, \mathrm{LS}_{2}, \mathrm{LS}_{3}, \mathrm{LS}_{\mathrm{n}}\right)$, in which the individual languages $\left(\mathrm{L}_{1}, \mathrm{~L}_{2}, \mathrm{~L}_{3}, \mathrm{~L}_{\mathrm{n}}\right)$ are embedded, crosslinguisitic interaction, and multilingualism factor. The author suggested that in order to understand the complex interrelationships among variables involved in multiple language learning over time, future studies of multilingualism should consider applying a dynamic systems theory approach, as well as future tests of language proficiency should take into account a holistic approach to examining the proficiency, which means testing the metalinguisitic awareness [Jessner 2008b]. Therefore, the focus of our study was to examine the role of multilingual proficiency and metalingusitic awareness in the context of cross-lexical interactions.

\section{The Study}

The aim of the study was to identify instances of cross-lexical interactions from two background languages and examine the role metalinguistic awareness and students' multilingual proficiency might have on the choice of lexis in the L3 production. We put forward several research questions and hypotheses: 
Research question 1:

1.Will the knowledge of Croatian as the first language be linked with the appearance of cross-lexical transfer in the Russian language?

Hypotheses 1 and 2:

H1: The knowledge of Croatian will be closely linked with cross-lexical transfer in Russian L3 production since Croatian and Russian are more formally similar as Slavic languages than it is the case with English and Russian.

H2: Croatian will have more hindering than facilitating effect in L3 Russian.

Research question 2:

2. Will the knowledge of English as the second language be linked with the appearance of cross-lexical transfer in the Russian language?

Hypotheses 3 and 4:

H3: The knowledge of English will be slightly linked with cross-lexical transfer in Russian L3 production.

H4: English will have more facilitating than hindering effect in L3 Russian.

Research question 3:

3.How will cross-lexical transfer in L3 Russian be connected with metalinguistic awareness with respect to students' proficiency in L3?

Hypotheses 5 and 6:

H5: Students with low level of L3 proficiency will show weaker metalinguistic awareness of the possible facilitation or constraint of prior languages and will do poorly on synonym provision task and there will be more L1 effect hindering the production of L3 lexis.

H6: Students with high level of L3 proficiency will show stronger metalinguistic awareness of the possible facilitation or constraint of prior languages and will do better on synonym provision task and there will be more facilitating effect of L2 on L3.

\subsection{Participant sample}

The sample consisted of 30 students, majoring in English and Russian $(\mathrm{N}=10)$, and majoring in Russian and other courses $(\mathrm{N}=20)$ at the Faculty of Humanities and Social Sciences of the University of Zagreb. Other courses students were engaged in included Linguistics $(\mathrm{N}=2)$, German $(\mathrm{N}=2)$, Spanish $(\mathrm{N}=1)$, Portuguese $(\mathrm{N}=1)$, Pedagogy $(\mathrm{N}=2)$, Information Science $(\mathrm{N}=1)$, Phonetics $(\mathrm{N}=1)$, Italian $(\mathrm{N}=3)$, Comparative Literature $(\mathrm{N}=2)$ and Turkish $(\mathrm{N}=1)$. In data analysis we did not divide the two groups, since the years of learning English as the first foreign language for the second subsample (those students who were majoring in Russian and other courses) did not show any deviations from the first subsample (students who were majoring in English and Russian).

Mean participant age was 20 . They were at the 1 st, $2 \mathrm{nd}, 3 \mathrm{rd}$ or 4 th year of the study at the university. For all students the first language was Croatian (L1). The first foreign language or the second language was English (L2) for most of the students. Only two students stated their second language was German, and their third language was English. However, students' self-assessment of language knowledge showed students' better knowledge in English than in German, and the years of learning the two languages did not differ. That is why we decided not to exclude these two students from the analysis, as in our methodology we dealt with English, Croatian and Russian cognates. Not for all students Russian was the third or second foreign language (L3) regarding the order of language acquisition, but we characterised it as an L3, since the third or additional language is often referred to as an L3, regardless of whether it is a third, fourth or sixth language [De Angelis 2007:10]. The average years of learning English varied from 12 to 15 years, and the years of learning Russian varied from 1 to 3 years. Most of 
Marina Jajić Novogradec Cross-lexical Interactions in Relation to Metalinguistic...

the students started learning Russian as a foreign language at the university. Therefore, all the students were beginners in learning Russian as L3.

\subsection{Instruments}

The language proficiency in Croatian, English and Russian was measured by students' self-assessment and the grade in English and Russian language courses. Although these measures seem to have certain limitations due to their subjectivity, they are still considered to be valuable measures of language proficiency. In order to measure cross-lexical interactions, the synonym provision task was used. The students were asked to read 15 sentences in Russian in which one word was underlined and to supply a synonym in Russian for the underlined word in each sentence. We had in mind students' various proficiency in the Russian language, so we provided sentences and synonyms in line with their Russian proficiency. Lexical items in the sentences were slightly beyond the subjects' proficiency in L3.

The task was based on a synonym/antonym provision task used by Ó Laoire \& Singleton [2009] and synonym provision task used by Letica Krevelj [2014]. As it was proved by previous research [Ó Laoire \& Singleton 2009; Letica Krevelj 2014], it was expected that the task would trigger either a conscious or an unconscious cross-lexical search in the process of retrieving an L3 lexical item that corresponds to the concept conveyed by the L3 item underlined in the sentence. Each underlined word had a translation equivalent in either Croatian or English that was only formally or both formally and semantically similar to the word in the Russian language.

The words were mostly true cognates in Croatian, English and Russian, words with formal similarity and the same meaning (e.g. Russ. akkuratno - Cro. tochno - Eng. reguliarno (regularly); Russ. polnost'iu - Cro. sovsem - Eng. absoliutno (absolutely); Russ. svedeniia - Cro. informacii - Eng. dannye (data); Russ. uiutnyi - Cro. udobnyi - Eng. komfortny$i$ (comfortable); Russ. skrytaia prichina - Cro. taina - Eng. sekret(secret); Russ. beglo - Cro. svobodno - Eng. fluentno (fluently); Russ. medicinskoe uchrezhdenie - Cro. bol'nica - Eng. gospital' (hospital); Russ. tochka zreniia - Cro. storona - Eng. aspect (aspect); Russ. sil'nyi - Cro. krepkii- Eng. intensivnyi (intensive)), some were false cognates in English and Russian (e.g. Russ. broshiury-Eng. prospekty(prospects); Russ. sovremennyi - Eng. aktual'nyi (actual); Russ. vkusno - Eng. delikatno (delicate); Russ. publika - Eng. auditoriia (audience); Russ. zavod - Eng. fabrika (fabric)), and there was one false cognate in Croatian and Russian (e.g. Russ. vozmozhnost'- Cro. sluchainost' (eng. possibility)), words with formal similarity, but different meaning.

The words were taken from the Russian National Corpus of spoken and written language. Students' metalinguistic awareness was examined by a retrospective task in which students were asked to write which language facilitated their choice of lexical item and which distracted it. The students were also asked to write additionaly the recall of lexical item, if it happened that there was no facilitating or hindering effect of the languages. Language background questionnaire also included students' age, courses studied and order of foreign languages learning, informal exposure to English and Russian, item on psychotypology at language system level and questionnaire on metalinguistic awareness including 13 sentence items. For metalinguistic awareness questionnaire students had to decide on the Likert scale from 1: I strongly disagree to 5: I strongly agree which of the given statements referred to them.

\section{Results}

Considering students' proficiency in the three languages, which was measured by their self-assessment, all students were highly proficient in Croatian and English, having in mind 
that Croatian was students' first language and English the second language. According to students' self-assessment, the knowledge of Russian was graded as an average, which can be justified by the fact that students considered themselves to be at the beginning of Russian language learning, and thus less proficient in Russian than in the prior foreign language.

Furthermore, respective to students' grade in Russian Language course, students were slightly more proficient in Russian, with an average grade of 3,7 that equals "very good" in the Croatian education system. We identified cross-lexical interactions of background languages in L3 production on the basis of previously defined cognates and lemmas of the output word, as well as the retrospective method, according to which we could clearly confirm transfer and students' metalinguistic awareness in L3 production.

According to the analysis of students' output words, overall results showed the Croatian language to be the main source of transfer and the language that mostly facilitated the L3 production (33,6\%), while English showed slight influence (13,5\%). It means that the first hypothesis (H1) was confirmed, but the second hypothesis (H2) was not. Croatian had more facilitating than hindering effect in L3 item production, especially for the following words: polnost'iu (Cro. sasvim; Eng. absolutely; Russ. sovsem; absoliutno) (53.3.\%); uiutnyi (Cro. udoban; Eng. comfortable; Russ. udobnyi; komfortnyi) (83.3. \%); skrytaia prichina (Cro. tajna; Eng secret; Russ. taina; sekret) (26.7. \%); medicinskoe uchrezhdenie (Cro. bolnica; Eng. hospital; Russ. bol'nica; gospital') (50.0\%).

We could also find some hindering effect of the language, but it was not as significant as it was the facilitating effect. The third hypothesis (H3) was confirmed, since English was slightly linked with the appearance of cross-lexical transfer. The fourth hypothesis (H4) was also confirmed because it had a more facilitating effect. The facilitating influence of English was significant for the following words: akkuratno (Cro. tochno; Eng. regularly, punctually; Russ. tochno; reguliarno; punktual'no) (23.3. \% for reguliarno; $10 \%$ for punktual'no) skrytaia prichina (Cro. tajna; Eng. secret; Russ. taina; sekret) (30\%); zavod (Cro. tvornica; Eng. factory; Russ. fabrika) (23.3. \% for fabrika; $6.7 \%$ for faktor).

The fifth hypothesis (H5) and the sixth hypothesis (H6) were partly confirmed, since there was a strong metalinguistic awareness recorded for each item, and a more facilitating effect of L1 and L2 on L3 item production in high proficiency students of Russian, with a significant effect of L1 on L3. There was also a strong metalinguistic awareness recorded for each item and a more facilitating effect of L1 and L2 on L3 item production in low proficiency students of Russian, with a significant effect of L1 on L3. The high and low proficiency students did not show any difference in correct and incorrect answers in the synonym provision task.

Irrespective of evident cross-lexical interactions from both languages, there were several compensatory strategies in L3 synonym production, as well as non written items. Croatian-based compensatory strategies consisted of the words, such as: letki, sovershenno, real'nyi, bystro, gledateli, gosti, posetiteli, poliklinika, bol'shoi. English-based compensatory strategies included the words: advertismenty, bukstor, visitori, medpunkt, posibilitet. The non written items may occur because of students' lack of the item knowledge or the context, as it was explained by the students in the retrospective task. According to the analysis of exposure to Russian and English, students' reports showed that there was a low use of Russian in everyday situations through four language skills - listening, reading, speaking, and writing, as opposed to a considerable use of Russian aimed at learning for Russian Language courses at the university. Therefore, the low exposure to Russian might have resulted in compensatory strategies and non-written items, which can also be the result of students' low proficiency.

According to the general questionnaire results on metalinguistic awareness, it was 
Marina Jajić Novogradec Cross-lexical Interactions in Relation to Metalinguistic...

found out that students were highly metalinguistically aware of the languages they were learning. The mean value was significant for 9 statements out of 13 included in the questionnaire. The significant statements of metalinguistic awareness were as follows: I can easily recognize similarities and differences between Russian and other languages I learn $(\mathrm{M}=4.07 ; \mathrm{SD}=$ $.71)$; I easily recognize errors in my first language $(\mathrm{M}=4.2 ; \mathrm{SD}=.85) ;$ I can easily notice errors in a foreign language $(\mathrm{M}=3.71 ; \mathrm{SD}=.85)$; I try to connect grammatical knowledge in Russian with my first and other foreign languages I know $(\mathrm{M}=3.92 ; \mathrm{SD}=.97) ;$ I try to connect similar words in first and other languages $(\mathrm{M}=4.46 ; \mathrm{SD}=.74) ;$ I try to find out the meaning of an unknown word in Russian with the help of all the language knowledge $(\mathrm{M}=4.21$; SD $=.95) ;$ In the classroom I notice similarities and differences between Russian and other languages $(\mathrm{M}=4.21 ; \mathrm{SD}=.78) ;$ I realize what errors I make in Russian and learn from them $(\mathrm{M}$ $=4.28 ; \mathrm{SD}=.80) ;$ During my regular Russian Language courses teacher points at similarities and differences between languages I know $(\mathrm{M}=3.78 ; \mathrm{SD}=1.13)$.

\section{Conclusion}

Our study revealed significant correlation between metalinguistic awareness and additional language learning regardless students' proficiency in L3 (Russian). Students' cross-lexical interactions were visible both in students with high proficiency in L3, and those with low proficiency. What we should consider while examining cross-lexical interactions, especially in relation to metalinguistic awareness, is metalinguistic awareness at the level of individual lexical item, which was in our case examined by the retrospective task, and metalinguistic awareness at the language systems' level, examined by the general questionnaire on metalinguistic awareness.

Students are usually aware of the similarities and differences between various subgroups of languages, but when they use the languages, whether formally or informally, their metalinguistic awareness is somewhat weaker or distracted due to the activation of all the languages in their mind. Having lexical transfer more evident from the Croatian language than from English can be justified by the role of another learner factor, and that is psychotypology, which has shown significant correlation with cross-lexical transfer from Croatian, since many students find Russian and Croatian languages (as both belonging to the Slavic subgroup of languages) similar at the language system level. Interestingly, one student pointed out the similarity between Russian and Croatian Kajkavian dialect.

Moreover, a high informal use of English contributed to the English language facilitating effect for some words. It is important to highlight that the facilitating effect was more significant for true cognates, while the hindering effect was more significant for false cognates. Future studies should examine more factors interacting in L3 Russian lexical production, like psychotypology, exposure to languages, recency of use. Multidirectional transfer is another matter the studies on cross-lexical interactions in multiple language acquisition should pay attention to $(\mathrm{L} 2 \rightarrow \mathrm{L} 3 ; \mathrm{L} 3 \rightarrow \mathrm{L} 2 ; \mathrm{L} 1 \rightarrow \mathrm{L} 3 ; \mathrm{L} 3 \rightarrow \mathrm{L} 1)$.

As far as glottodidactic implications are concerned, the role of teachers in the foreign language classroom is inevitable: teachers should know what languages students have been learning; present language materials with true, partial and false cognates as much as possible; enhance students' awareness of similarities and differences between the languages they are learning, and provide both receptive and productive use of lexis in the classroom. The authors of coursebooks and other language materials should also have another essential role: to adapt language presentation in the coursebooks to learners' experience in foreign language learning, having in mind the knowledge of learners' other languages, both L1 and L2. 


\section{References}

Angelovska, T., \& Hahn, A. (2012). Written L3 (English): Transfer Phenomena of L2 (German) Lexical and Syntactic Properties. In Gabryś-Barker, D. (Ed.), Cross-linguisticInfluences in Multilingual Language Acquisition. Heidelberg, New York, Dordrecht, London: Springer, pp. 23-40.

De Angelis, G. (2007). Third or additional language acquisition. Clevedon, Buffalo, Toronto: Multilingual Matters.

Gabryś-Barker, D. (2006). The Interaction of Languages in the Lexical Search of Multilingual Language Users. In Arabski, J. (Ed.), Cross-linguistic Influences in theSecond Language Lexicon. Clevedon, Buffalo, Toronto: MultilingualMatters Ltd., pp. 144-166.

García, O. (2008). Multilingual language awareness and teacher education. In Cenoz, J., \& Hornberger, N. H. (Eds.), Encyclopedia of Language and Education, 2nd Edition, Volume 6: Knowledge about Language. Springer Science+BusinessMedia LLC., pp. 385-400.

Gibson, M., \& Hufeisen, B. (2003). Investigating the role of prior foreign language knowledge. In: Cenoz, J., Hufeisen, B., \& Jessner, U. (Eds.), The Multilingual Lexicon. New York, Boston, Dordrecht, London, Moscow: Kluwer Academic Publishers, pp. 87-102.

Hall, C.J., \& Ecke, P. (2003). Parasitism as a default mechanism in L3 vocabulary acquisition. In: Cenoz, J., Hufeisen, B., \& Jessner, U. (Eds.), The Multilingual Lexicon. New York, Boston, Dordrecht, London, Moscow: Kluwer AcademicPublishers, pp. 71-86.

Herdina, P., \& Jessner, U. (2002). A Dynamic Model of Multilingualism. Clevedon, Buffalo, Toronto, Sydney: Multilingual Matters Ltd.

Jajić Novogradec, M. (2017). Međujezični utjecaji u ovladavanju engleskim leksikom -uloga skorašnjosti i jezičnoga znanja (Cross-linguistic influence in English vocabularyacquisition - the role of recency and language proficiency). Unpublished doctoralthesis. University of Zagreb, Zagreb.

Jarvis, S., \& Pavlenko, A. (2008). Crosslinguistic Influence in Language and Cognition.New York, London: Routledge Taylor \& Francis Group.Jessner, U. (2003). The nature of cross linguistic interaction in the multilingual system. In Cenoz, J., Hufeisen, B., \& Jessner, U. (Eds.), The Multilingual Lexicon. New York, Boston, Dordrecht, London, Moscow: Kluwer Academic Publishers, pp. 45-55.

Jessner, U. (2006). Linguistic Awareness in Multilinguals. English as a ThirdLanguage. Edinburgh: Edinburgh University Press.Jessner, U. (2008a). A DST Model of Multilingualism and the Role of MetalinguisticAwareness. The Modern Language Journal, Vol. 92, No. 2, 270-283.

Jessner, U. (2008b). Teaching third languages: Findings, trends and challenges. Language Teaching, Vol. 41, No. 1, 15-56.

Lasagabaster H. D. (1998a). Metalinguistic awareness and the learning of English as anL3. ATLANTIS, Vol. XX, No. 2, 69-79.

Lasagabaster D. (1998b). The treshold hypothesis applied to three languages in contactat school. International Journal of Bilingual Education and Bilingualism, Vol. 1, No. 2, 119-133.

Letica Krevelj, S. (2014). Cross-linguistic interaction in acquiring English as L3: Roleof psychotypology and L2 status. Unpublished doctoral thesis. University of Zagreb, Zagreb.

Lindquist, C. (2009). The use of the L1 and the L2 in French L3: examining crosslinguistic lexemes in multilingual learners' oral production. International Journal ofMultilingualism, Vol. 6, No. 3, 281-297.

Navés, T., Miralpeix, I., \& Celaya, M. L. (2005). Who Transfers More....and What? 
Marina Jajić Novogradec Cross-lexical Interactions in Relation to Metalinguistic...

Cross-linguistic Influence in Relation to School Grade and Language Dominance inEFL. International Journal of Multilingualism, Vol. 2, No. 2, 113-134.

Ó Laoire, M., \& Singleton, D. (2009). The role of prior knowledge in L3 learning anduse. In: Aronin, L., \& Hufeisen, B. (Eds.), The Exploration of Multilingualism. Amsterdam, Philadelphia: John Benjamins Publishing Company, pp. 79-102.

Tkachenko, N. (2011). The relative influence of English (L2) vs. Russian (L1) on thetranslation from Swedish (L3) into Russian depending on proficiency in L3. Centre forlanguages and literature, General linguistics, Master's Thesis [Electronic source]. URL:http://lup. lub.lu.se/luur/download?func $=$ downloadFile\&recordOId=2545119\&fileOId=25459 (retrieval date: 09.09.2012)

Tremblay, $M-C$. (2006). Cross-linguistic influence in third language acquisition: Therole of L2 proficiency and L2 exposure. CLO/OPL, No. 34, 109-119.

\title{
МЕЖЪЯЗЫКОВЫЕ ЛЕКСИЧЕСКИЕ ВЗАИМОДЕЙСТВИЯ ЧЕРЕЗ ПРИЗМУ МЕТАЛИНГВИСТИЧЕСКОГО ЗНАНИЯ И ПОЛИЛИНГВИЗМА (ПРИ ИЗУЧЕНИИ РУССКОГО ЯЗЫКА КАК ВТОРОГО ИНОСТРАННОГО)
}

\author{
Марина Яйич Новоградец \\ Преподаватель кафедры русского языка \\ Факультет социально-гуманитарных наук, Университет Загреба \\ Ул. Ивана Лючича, 3, Загреб, Республика Хорватия
}

В статье рассматривается проблема межъязыковых лексических переносов и поддерживающего влияния нескольких языков, которыми владеет один и тот же человек. В качестве факторов, влияющих на этот процесс, автор рассматривает наличие металингвистических знаний и уровень владения данными языками. Респондентами выступила группа хорватских студентов, имеющих высокий уровень владения английским языком как первым иностранным и в разной степени владеющих русским языком как вторым иностранным. Уровень владения этими языками оценивался, исходя из субъективных оценок самих учащихся, а также опираясь на их академические оценки по соответствующим предметам. Испытуемым предъявлялись фрагменты текстов на русском языке, содержащие выделенную малоизвестную для них лексику, и предлагалось подобрать подходящие, по их мнению, русскоязычные синонимы. При этом выделенные единицы были подобраны таким образом, что каждая из них имела практически полное (формальное и семантическое) или частичное (только формальное) соответствие в хорватском и английском языках. Предполагалось, что такая постановка задачи будет способствовать сознательной или неосознанной активации лексических связей между языками, которыми владеет индивидуум.

Исследование выявило, что к факторам, влияющим на становление многоязычной компетенции у изучающих иностранные языки студентов, следует отнести не только уровень владения ими соответствующих языков и наличие у них метаязыковых знаний, но и ряд других факторов, таких как частота использования изучаемых языков, психотип учащихся, новизна предъявляемого материала и др.

Ключевые слова: межъязыковое лексическое взаимодействие, металингвистическое знание, владение несколькими иностранными языками, английский как первый иностранный язык, русский как второй иностранный язык 